\title{
Research on the training of students' practical ability in the professional skill competition of computer major
}

\author{
Wei Guanghui \\ ChongQing College of Electronic Engineering, computer college,ChongQing,401331,china \\ qdbiq@163.com
}

\begin{abstract}
Key words: vocational skills competition; higher vocational colleges; computer major; practical ability; way
\end{abstract}

\begin{abstract}
The goal of higher vocational colleges is to provide the society with advanced technology applied talents. Practical ability is the basic requirement for the graduates of higher vocational colleges at present, and it is also one of the indispensable basic abilities in the future. This paper analyzes the impact of vocational skills competition on the ability of computer major students in higher vocational colleges, and puts forward the ways to improve the ability of computer majors in higher vocational colleges.
\end{abstract}

\section{Introduction}

For a country, both academic and research personnel, but also need to engage in the operation of talent, so that is a reasonable structure of talent. After entering the twenty-first Century, many countries in the world have vigorously develop vocational education, and pay more attention to the quality of vocational education. In 2012, China's Ministry of human resources and social security approval, set up a research center China world skills competition, study the occupation skills competition and occupation by the Tianjin University of technology is responsible for the management, in order to improve China's athletes competition level, to enhance the level of skills of the occupation of our country, clear our skilled personnel culture, and provide a scientific basis for constructive training and development direction. Held in Brazil St Paul forty-third session of the world skills competition, there are more than 1200 players from the world organization of the skills of 59 member countries and regions participating, which fully shows the skills competition by many countries international attention, has great influence in the world.

Based on computer professional as an example, the higher vocational college students occupation skill practice ability status and occupation skills contest has carried on the analysis to the computer professional influence, and puts forward the main ways of Occupation Skills Contest for students' practical ability.

\section{The current situation of students' practical ability in Higher Vocational Colleges}

Students entering higher vocational colleges generally lack self-confidence, self control ability is poor, the enthusiasm of learning is generally not high, the foundation is generally poor. Higher vocational college students have to lay a good foundation in the middle school stage, basic knowledge is weak, especially in mathematics and English is relatively poor, and the computer professional courses for English and math requirement is higher, which leads to most of the students have fear. In the course of computer practice course in general, only a few students have strong 
practical ability, and most of the students will not take the initiative to practice, not to think about how to complete the content of practice, such practice ability is unable to meet the needs of enterprises and society, thus to improve the practical ability of students.

\section{The influence of vocational skills competition on computer major in Higher Vocational Colleges}

In China, occupation skills contest today, to a very large role in promoting the development of computer specialty in higher vocational colleges, including the following four aspects: one is to improve the students' practical skills, increase the social recognition of vocational education; two is through the combination of theory and practice, and promote the curriculum reform teaching reform, pay more attention to the cultivation of students' skills; three is to cultivate the students' team spirit and team spirit, and occupation skill, occupation ethics and self-learning ability; four is to realize the quality of teaching, students' comprehensive quality and improve the employment rate of students.

Through the computer professional occupation skills contest, the construction to the mode of training base construction of computer professional from the computer professional talent training, from the computer specialized curriculum system reform to the construction of teachers of computer specialty, the characteristics of the occupation skills contest, make clear training objectives more and more training base construction enterprise, the reform of curriculum system more professional, more teachers team construction skills.

Occupation skill competition of higher vocational computer professional greatly subverts the traditional teaching mode of higher vocational education, higher vocational colleges with innovation in occupation skills contest this platform bold exploration, gradually formed the task driven work process oriented theory and practice integrated teaching mode, occupation skills contest has become a booster of numerous computer major in Higher Vocational Colleges to improve the teaching quality. On the one hand, through the occupation skills contest, the computer specialized curriculum pay special attention to the unified theory courses and training courses, in order to increase the skills competition project and the latest enterprise application project as the carrier, to guarantee the students' practical skills to improve.

\section{The main way to cultivate students' practical ability in vocational skills competition}

The main ways of the training of students' practical ability of computer professional vocational skills competition in higher vocational colleges include the following aspects.

Equipment to ensure training. Higher occupation skill contest of experimental equipment, most of the use of foreign advanced equipment, the equipment is not only need to use the skills competition, and is used in the production practice in enterprise, for example, computer skills competition, generally use the equipment in the United States Cisco company, domestic H3C, such as ZTE, Ruijie router switch and firewall, and other products, these products in the size of the domestic enterprises are in use, to ensure the proper use of these products in the students' skills competition process, and has the ability after graduation to enter the actual working environment in the use of these devices, which requires all colleges and Universities to increase hardware training equipment investment, as far as possible the introduction of some enterprises are using, and the skills competition need to use the equipment, to create a good training conditions for students, make students The training environment is highly simulated in the practical working environment. Higher vocational colleges through the occupation skills contest, not only promoted the construction of 
training bases, improve the training conditions, the training equipment is more close to the industry standard, more close to the real business environment and work scene.

Promoting students' learning through competition. In Chinese, many of the students in Higher Vocational Colleges to lose confidence in learning, a serious shortage of power through learning, skills competition, can provide a platform to display their abilities to students, stimulate their interest in learning, to help them regain confidence, students have to study the interest in learning, and will have the motivation to learn and the goal of learning. Higher vocational colleges can stimulate students by vigorously promoting the skills competition, arouse their interest in learning, mobilize the enthusiasm of learning. On the employment side, the students to participate in the competition of the employment situation has a great improvement, excellent results can be directly into the more outstanding enterprises.

Through the vocational college computer professional skills competition, can promote the development of students' comprehensive quality. Occupation skill competition requires not only superb professional skills, students have good occupation moral, physical and psychological quality, language communication and teamwork ability, which will promote the higher vocational colleges to improve the core competence of students occupation training, improving students' comprehensive qualities; and promote students to create a good learning atmosphere of occupation education, competition of the students put forward higher requirements on professional ability, social ability, occupation ability level, students participating in all aspects of their training and performance.

Vocational education faces the goal of all people, and the vocational education is fair. In order to avoid only a few students to learn, while ignoring the majority of not participating students, competition can be divided into two stages, the first stage is the competition for all computer science students, according to the national and provincial standards for training, and then according to their study of professional expertise, attended by school organizational skills contest, through all of the occupation skill competition, to create a strong learning atmosphere, making the overall enhancing the teaching effect.

Improving teaching content and teaching method according to the guiding ideology of the competition. The characteristics of the computer industry is the knowledge update time is short, the product replacement frequency is high, the emergence of new technology quickly, to keep up with the needs of the industry, will be teaching content for colleges to do real-time adjustment, according to industry demand plan to cultivate talents. While the occupation skills contest was closely followed by the actual production enterprises, reflecting the progress and trend of the industry and social development, reflecting the industry's new occupation skill requirements, and the content and standard of competition contest project teaching has also been greatly enriched, teachers can select the title contest of occupation teaching to the students, let the students to realize the frontiers of knowledge of the industry and should have the occupation skills, do so to a large extent on education and solve the actual production situation to escape.

Strengthen the construction of Teachers. Most of the teachers of computer specialty in higher vocational colleges are graduated from university candidates to the school to teach the professional theory level is generally high, but the actual operation ability is relatively deficient in the teaching process, pay attention to the explanation of theoretical knowledge and practical operation of relatively small, compared with the practice in the enterprise people, proficiency in the production technology, and new production technology is a big gap, which will lead to teachers' computer knowledge and society and is out of the times.

For example, network cabling, network technology is a computer professional students should master, if teachers have participated in practice and new technology of wiring, cabling without 
tracking learning, is bound to the details of the comprehensive wiring in the process not to teach and show. In Higher Vocational Colleges occupation skills contest as an opportunity to guide teachers to arrange a business exercise, on the other hand, invite experts in business and industry training for teachers, teachers also should pay attention to the problems to be solved urgently and enterprises and related professionals to solve these problems when the ideas and solutions. So teachers can understand the real needs of society and enterprises, professional development trends and trends, the emergence and application of new technologies, and so on.

Establishing school enterprise cooperation. Higher vocational colleges should timely adjust the specialty structure according to the needs of the enterprise, to further promote the cooperation of the depth of integration, promote the students' practical ability and rapid development of education, higher vocational colleges should strengthen the cooperation with enterprises, provided by the enterprises R \&amp; D projects, sponsorship arrangements, real judges, expert lectures, bonus prizes, winners will be applied to production. This will be achieved in Higher Vocational Colleges and enterprises benefits: the school can cultivate industry much-needed talent, companies gain new employees, new products, new technology; school won the opportunity to practice education, improve the quality of personnel training, both sides realize win-win and joint development, and truly become a community of interests.

\section{Conclusion}

Based on computer professional as an example, analyzes the main ways to participate in the occupation skills contest to cultivate students' practical ability, discusses the occupation skills contest is an important means of training and selection of outstanding talents, but also an important way to improve the quality of workers, promoting employment and re employment. By taking part in the vocational skills competition, to cultivate talents with high skill talents and enterprises, to highlight the essence of higher vocational education, to make higher vocational education better for enterprises, to serve the society.

\section{Reference}

[1] WANG Jun. The 2014 National Vocational Skills Competition to Forecast and Analysis of Logistics[J]. Logistics Sci-Tech,2014(4):139-141.

[2] Ju Xitian, Zhang ChuiXiang. Review of the National Skills Competition occupation colleges [J]. Vocational \& Technical Education Forum, 2012(19):79-82.

[3] Jong Yuping,Liang Li. Cultivation of innovative thinking of Computer Major Students[J]. Education and career, 2014(8) 122-123.

[4] Guao Wa. How to improve the ability of computer major students to work in Higher Vocational Colleges [J].China Management Informationization, 2013 16(21) 105-106.

[5] Huang Yu. On the promotion of vocational skills competition to higher vocational education [J].Education Teaching Forum,2013(52) 189-190.

[6] Li MingYu, Li Boxia. Construction of talents training mode in Higher Vocational Education from the perspective of vocational skills competition [J].Education and career,2014(8) 33-34.

[7] Peng Xuepeng. Contest Participating to Replace Training: An Effective Way of Cultivating the Higher Vocational College Student's Professional Quality[J].Journal of Changzhou Vocational College of Information Technology,2012 (5):84 86. 
[8] Zhang Xiaoju. Skill contests and teaching reforms [J].Journal of Shijiazhuang Vocational Technology Institute,2011(2):35-39. 